\title{
Beyond the human genome: Microbes, metaphors and what it means to be human in an interconnected post-genomic world
}

Brigitte Nerlich and Iina Hellsten

Professor Brigitte Nerlich (University of Nottingham, UK) (corresponding author) Institute for Science and Society, University of Nottingham, Law and Social Sciences Building, West Wing, University Park, Nottingham, NG7 2RD

Tel: 0115 8467065; Fax: 0115 8466349; E-mail: brigitte.nerlich@nottingham.ac.uk

Dr Iina Hellsten (VU University Amsterdam, The Netherlands)

Athena Institute for Research on Innovation and Communication in Health and Life

Sciences, Faculty of Earth and Life Sciences, De Boelelaan 1085, 1081 HV

Amsterdam, The Netherlands,

Tel. 003120 5986212; Fax. 003120 5987027; E-mail. iina.hellsten@falw.vu.nl

\begin{abstract}
Four years after the completion of the Human Genome Project, the US National Institutes for Health launched the Human Microbiome Project on 19 December 2007. Using metaphor analysis, this article investigates reporting in English speaking newspapers on advances in microbiomics from 2003 onwards, when the word 'microbiome' was first used. This research was said to open up a 'new frontier' and was conceived as a 'second human genome project', this time focusing on the genomes of microbes that inhabit and populate humans rather than on the human genome itself. The language used by scientists and by the journalists who reported on their research employed a type of metaphorical framing that was very different
\end{abstract}


from the hyperbole surrounding the decipherment of the 'book of life'. Whereas during the HGP genomic successes had been mainly framed as being based on a unidirectional process of reading off information from a passive genetic or genomic entity, the language employed to discuss advances in microbiomics frames genes, genomes and life in much more active and dynamic ways.

Keywords: microbiome, microbes, metaphor, self, life, Human Microbiome Project 


\title{
Beyond the human genome: Microbes, metaphors and what it means to be human in an interconnected post-genomic world
}

\author{
A friend of mine asked me recently what field \\ might strike the popular consciousness in the \\ coming years. Could it be that it will be the \\ realization that we are all "superorganisms" [...] \\ and that our health does not only depend on our \\ personal genome [...] and our environment, but \\ also on the extended genome provided by our very \\ private microbiome? (Anonymous, 2008)
}

\section{Introduction}

In the year 2000 the near decipherment of the human genome was celebrated around the world. Researchers seemed to have opened the 'book of life' and gained insights into the language of God. Soon afterwards various post-genomic enterprises began to flourish, alongside an intensive study of the language and metaphors used to publicize, debate or sell the human genome project (Nerlich \& Kidd, eds., 2006 and many more). From sequencing human and animal genomes, research went on to study their functions in functional genomics, compared them in comparative genomics and examined their structure or architecture. Others took the techniques developed during the Human Genome Project (HGP) further and began to study "patterns in how genes are transcribed into messenger RNA, the chemical that carries the instructions for forming proteins (transcriptomics), in the way genes are expressed as proteins (proteomics), and in how they influence the chemicals that control our cellular biochemistry and metabolism (metabolomics)" (NERC, 2006). 
Many more -omes and -omics emerged, including, in 2007, the study of the microbiome as part of the Human Microbiome Project (HMP).

At the same time as excitement about the HGP grew systems biology became a major new field of research, that is, the study of the interactions between the components of biological systems, and how these interactions give rise to the function and behavior of that system. Systems biology emerged, in part, as a reaction against a mainly reductionist approach in genetics and genomics and is now teaming up with bioengineering in the new field of synthetic biology. As Denis Noble said in his book The Music of Life:

Systems biology $[\ldots]$ is about putting together rather than taking apart, integration rather than reduction. It requires that we develop ways of thinking about integration that are as rigorous as our reductionist programmes, but different [...]. It means changing our philosophy, in the full sense of the term. (Noble, 2006a: 21)

This change of philosophy also implies a change in language. Alongside advances in genetics and genomics, increasing numbers of social scientists were engaged in questioning the language and metaphors that had been used traditionally in genetics and genomics, such as the blueprint metaphor for the gene and the book of life metaphor for the genome. Scientists themselves put forward proposals to change prevailing metaphors (Avise, 2001; Porta, 2003; Pappas, 2005; Noble, 2006a, Ouzounis \& Mazière, 2006; see Knudsen, 2005; Lopez, 2007 and many more). Some of these efforts to change the linguistic and metaphorical landscape of genetics and genomics were reviewed by Turney (2005) and Nerlich \& Hellsten (2005). They found that despite various shifts, transformations and critiques of traditional genomics metaphors, the language used to deal with the human genome and other 
post-genomic developments had not changed significantly during the post-genomic era. However, perhaps this finding was based on a too narrow focus on the HGP alone.

In this article we want to shift the focus of attention from human genetics and genomics towards microbial genomics (and the interaction between the two) and examine whether developments in this field challenge more openly the still rather deterministic, reductionist and human-centred language which has prevailed in human genetics and genomics up to now.

\section{Context}

As early as 2001 two microbiologists, David Relman and Stanley Falkow, set out their vision for a second human genome project, which eventually led to the announcement of the HMP -- the focus of this article. They stressed that:

The human body is host to a myriad of microorganisms. We are still woefully ignorant of the composition and variability of our endogenous microflora. Many of these microorganisms depend on humans for their survival, and yet we still do not fully appreciate to what extent human life is dependent on its microflora. In the spirit of the recent 'human genome project' and in the hopes of capturing the imagination of the broad scientific community, it is time to embark on a comprehensive genomic inventory of the large portion of cellular life within the human body that has been ignored so far, the endogenous microflora. A large-scale genomic sequence survey of the four major microbial niches within the human body, the mouth, intestinal tract, vagina and skin would help to fill crucial gaps in our understanding of human evolution, development, immune system function and disease. It should require no leap of faith to recognize that such an 
inventory would also contribute substantially to the scope of known functional diversity in the biosphere. The human biome is as much an unexplored frontier as the collection of life found at deep-sea thermal vents, if not more so. (Relman \& Falkow, 2001)

Deciphering the human genome had been celebrated by the then President of the United States, Bill Clinton, as reaching a new frontier (see Nerlich et al. 2002). With this article another scientific frontier is opened up for exploration and the human body becomes, as Relman declared a year later, a "microbial observatory" (Relman, 2002). In 2005, Relman spoke yet again about this second human genome project, this time not in a scientific journal but in a lecture in which he explained that we are 'never alone'.

Most of us are not used to thinking of ourselves as "communities," but that is what we are. Humans have 1013 cells, but host 1014 microbes. "In other words, we are 10 parts microbe, and one part human," Relman noted. "We are clearly outnumbered." (McManus, 2005)

At the same time as scientists like Relman asked for an exploration of the human biome, others went to explore another type of ecology, the Ocean biome. This study of microbial population genomics and ecology was, according to the marine biologist Edward DeLong (2004) and others (Doney et al., 2004), yet another 'new frontier'. We want to investigate here how this type of research also opened up a new metaphorical frontier in the popular representation of both genetics and microbes. Researchers involved in this new post-genomic enterprise clearly speak a different language compared to those involved in the HGP, as their focus is on interactions, 
communities and ecologies, rather than single 'letters' (bases), 'chapters' (chromosomes) or 'books' (genomes).

At the same time, popular, especially media discourses about microbes are mainly framed by negative and fear-inducing metaphors, where microbes invade and contaminate bodies and where the public is exhorted to wage constant war against them in hospitals, homes and public spaces. Microbes, especially so-called superbugs, are generally regarded as bad and as having to be eliminated (see Tomes 1998). As microbiomics emerged at a time of genomic hyperbole regarding the HGP on the one hand and microbial hyperbole leading to germaphobia on the other, it is important to ask what it means to study microbes as part of this second human genome project, both in terms of the language used and in terms of the answers this might suggest to the pervasive question: What does it mean to be human?

\section{The Human Microbiome Project}

Four years after the completion of the HGP, the US National Institutes for Health (NIH) launched the HMP on 19 December 2007 (and on 16 October 2008, when we finalized this article, the International Human Microbiome Consortium was launched). The NIH's HMP is a five-year multinational study of "the collection of all the genomes of all micro-organisms present in or on the human body" (NIH, press release 19 December, 2007). The HMB was announced with much less fanfare than the HGP and other post-genomic enterprises. This launch was reported by some news outlets in the US but went more or less unnoticed in the UK, unlike synthetic biology, which was popularised by Craig Venter, of human genome fame, on a promotional tour of Europe in the autumn and winter of $2007 / 08$.

The HMP builds on yet another post-genomic project, the study of the metabolome inside metagenomics. According to an educational booklet based on a 
US National Academies report entitled Understanding our Microbial Planet: The New Science of Metagenomics,

Metagenomics is an emerging field in which the power of genomic analysis (the analysis of all the DNA in an organism) is applied to entire communities of microbes, bypassing the need to isolate and culture individual microbial species. In Greek, meta means "transcendent." In its approach and methods, metagenomics transcends individual genes and genomes, enabling scientists to study all of the genomes in a community as a whole. (The National Academies, 2007)

As we have seen, such communities of microbial organisms can be found in the global ocean and the human body. Both are 'ecosystems' harbouring a multitude of micro-organisms. As the NIH pointed out when announcing the HMP,

The Microbiome is the full collection of microbes (bacteria, fungi, viruses, etc.) that naturally exist within the human body. Initiatives in this area would focus on developing a deeper understanding of these communities of microbes in order to determine how they affect human health. $(\mathrm{NIH}, 2007)$

Indeed some claim that understanding these complex interactions will lead to the 'next revolution in biology' (Goldenfeld \& Woese, 2007). Let us now examine whether the language used in reporting on these new scientific developments reflects such promises as it did when the decipherment of the book of life was announced, which was promised to reveal the language of God, or whether a more modest announcement is reflected in a more modest use of metaphors. 


\title{
Aims and objectives
}

When launching the HMP, the NIH listed a host of ethical, legal and social issues that could be explored as part of this overall project. Many of these questions can perhaps only be addressed in the US where the sampling of the microbiome from human body sites involving volunteers is taking place. However, one question struck us as particularly pertinent to our own interests.

\footnotetext{
"What will be the likely impact of human microbiome research on existing concepts of 'self' and 'personal identity'?
}

To which we would add:

\begin{abstract}
What will be the likely impact of human microbiome research on existing answers to the question: What is life? What does it mean to be human? What counts as a 'human body'?
\end{abstract}

We will, obviously, not be able to find complete answers to such deep questions. We shall focus only on the metaphorical framing of these answers in the English speaking press when reporting on advances in microbiomics.

\section{Material and method}

In order to provide a provisional answer to these questions and to compare and contrast results with analyses of metaphorical media framing of advances in genetics carried out before, we searched Lexis Nexis Academic for articles published over two months in English speaking newspapers, using the keyword 'microbiome' (that is, between 19 December 2007, the date of the NIH press release, and 19 February 
2008). We found only 6 articles making reference to the microbiome, of which 5 covered the announcement in December 2007 and one was an obituary of Joshua Lederberg, a pioneer in this field who died in January 2008. We then searched Lexis Nexis again using the keyword 'microbiome' and extended the search backwards to when the term 'microbiome' was first used by the media. This gave us a small corpus of 25 articles published between 2003 and 2007 (we excluded the obituary from our analysis, published in January, 2008). The data set consisted of the following articles published in English speaking newspapers worldwide (those that covered the announcement are highlighted):

- McClatchy-Tribune Business News (3) (US)

- National Post (3) (1 on announcement) (US)

- The Washington Post (3) (1 on announcement) (US)

- Belfast Telegraph (1) (UK)

- The Boston Globe (1) (US)

- The Daily and Sunday Telegraph (London) (1) (UK)

- Daily Post (Liverpool) (1) (UK)

- The Gazette (Montreal) (1) (Canada)

- The Independent Extra (1) (US)

- The Milwaukee Journal Sentinel (1) (US)

- New York Sun (1) (US)

- The New York Times (1) (US)

- Newsday (1) (US)

- San Diego Union-Tribune (1) (US)

- South Bend Tribune (1) (US)

- The Spokesman-Review (1) (US)

- The State Journal-Register (Springfield, IL) (1) (US)

- Sunday Tribune (South Africa) (1)

- The Times \& Transcript (New Brunswick) (1) (Canada)

Of these, three articles were duplicates. We also included in our corpus articles published in magazines (covered in Lexis Nexis) over the same time period: Two were published in Newsweek, one in New Scientist, one in The Economist.

To analyse this small corpus, we used a type of conceptual metaphor analysis inspired by Lakoff \& Johnson's book Metaphors We Live By (1980) as applied to the social study of science and society (e.g. Nerlich \& Dingwall, 2003). According to the cognitive linguistic view of metaphor, metaphors help us understand an abstract or 
inherently unstructured subject matter in terms of a more concrete, more highly structured subject matter. They are mostly used in science to make the unfamiliar familiar. We shall focus in particular on how scientists themselves use metaphors as such framing devices, which then enable journalists and readers to 'see' or understand microbes, genomes and humans in new ways, ways that appear however to be entirely natural and sensible. This has wider implications that go beyond press coverage. As the literary critic Ivor A. Richards wrote, a command of metaphor plays a role in "the control of the world that we make for ourselves to live in" (1936:1356). In this case there are implications for human health and well-being, as well as perhaps for our planet's well-being.

In cognitive linguistics, conceptual metaphors, such as ARGUMENTS ARE WAR (and their linguistic realisations, e.g. "He spearheaded the debate"; "He surrendered to her argument", etc.) are seen as mappings across at least two conceptual domains: the conceptual source domain (e.g. war) and the conceptual target domain (e.g. arguments). These mappings are not arbitrary. Rather, they are grounded in our everyday experience of the body and the world we live in. Our conceptual metaphor system is for the most part unconsciously and automatically accessed and processed. We only become conscious of it when highly poetic and novel metaphors are created.

Following Schmitt (2005), we analysed our small corpus in a simple qualitative way using a step-by step-approach: (1) texts were examined by means of a word-for-word or close-reading analysis for their use of metaphors; (2) a collection of metaphorical expressions together with their immediate contexts was established; (3) these expressions were sorted under higher level labels for 'conceptual metaphors'. We initially wanted to count the conceptual metaphors and the metaphorical expressions they subsume, but then abandoned this attempt at quantification, as many metaphorical expressions could be counted as falling under a 
variety of conceptual metaphors which formed a conceptual hierarchy to which we shall come back in the next section.

\section{Analysis: From the book of life to communities of life}

In the following we shall first provide an overview of the development of the English press coverage of advances in microbiomics, from 2003 onwards, highlighting in particular the contributions made by some pioneers in the field (we shall provide their names in brackets behind metaphorical expressions used by them). We shall then discuss the main metaphorical framings in more detail. When analyzing the press coverage around micobiomics, it became clear that many of the metaphorical framings used were not invented by journalists, reporters or science writers, but by the scientists themselves. Whether these metaphors are used by scientists in their daily lives or whether they are only used when 'translating' their research for media purposes cannot be determined here. It is however important to note that this finding is in line with others (Nerlich \& Halliday, 2007), and shows that some assumptions made by those studying science communication have to be questioned. All too often failures in science communication are blamed on inaccuracies in news coverage on the one hand and on irrational beliefs held by the public on the other. The issue as to how metaphorical framings by scientists contributes to successes and failures in science communication is often overlooked.

The term 'microbiome' was first used in the English speaking press, as indexed by the LexisNexis database, on 1 April 2003 in a long article for the New York Times entitled: "Aliens inside us: A (mostly friendly) bacterial nation". The phrase 'bacterial nation' had been used by Jeffrey Gordon, a microbiologist who had just published a paper in Trends in Microbiology (Gordon et al., 2003). He became one of the most prolific metaphor users in the press coverage overall. Two more 
articles explored this topic in 2003 , one of them written by Joshua Lederberg entitled "We must find a new inner peace".

Two metaphors are important in this early coverage, one, according to which bacteria are a community, but a community that is conceptualised according to what we know about human communities (a nation) or what we speculate about in terms of extraterrestrial communities (aliens), and the other according to which war against bacteria should be replaced by peace. In the press coverage that followed the first metaphor would predominate over the second.

There was a gap of three years before another article appeared in 2006 using the term 'microbiome'. This was published in the National Post and entitled "Humans partly bacteria: Study". Three other articles appeared in 2006, all, it seems prompted by a study on the skin microbiome carried out by Martin Blaser and, as before, published in Science (Blaser, 2006). Blaser too was a prolific metaphor creator. The headlines already indicate uses of various underlying or conceptual metaphors: "It's the bugs in our gut which keeps us so healthy...", "Legion of little helpers in the gut keeps us alive", "Can't live without these bugs". They all focus on 'what bacteria do for us' and conceptualise bacteria as agents, but, unlike those nasty 'superbugs', that were so much in the news at the same time (Crawford et al., 2008), as friendly agent, even expert friends, or as Gordon expressed it, "master physiological chemists".

Nine articles appeared in 2007 before the announcement of the HMP. They reported on research published in Science by Steven R. Gill, Gordon, Claire FraserLiggett and others involved in the Human Distal Gut Microbiome (Gill et al., 2007).

Only five, very short, articles reported the announcement of the HMP itself in December 2007, an indicator that the timing of this announcement just before Christmas was perhaps unfortunate. Some of the 2007 headlines are again indicative of emerging uses of conceptual metaphors as well as puns: "Wee friends: Bacterial 
buddies make life - and you - possible", "Gut healing", "Gut feel about bacteria", and, best of all: "Microbes are us". Here microbes are seen not only as agents but as groups, as groups of friends, as healers, and, what is more, as merging with 'us' as humans. Barriers between humans and microbes which tend to dominate discourses of 'unfriendly' bacteria are abolished completely.

When looking more closely at the metaphorical framing, it emerged that one conceptual metaphor underpins almost all the others used in the corpus, namely the one according to which microbes are personified as having quasi-human agency (see also Crawford et al., 2008). The underlying conceptual metaphor is:

- MICROBES ARE AGENTS (in cognitive linguistics conceptual metaphors are traditionally marked by the use of small capitals)

Fictional and factual knowledge of various types of agents and their behaviour then structured other conceptual metaphors, such as:

- Microbes ARE ALIENS

- MicRobes ARE ANIMALS

- Microbes aRe COMmUnicators

As agents live in social groups, other conceptual metaphors were linked to these, namely:

- MicRobes aRe social GROUPS

- Microbes aRe nATIONS

- MICROBES ARE NEIGHBOURHOODS

An important cluster of metaphorical expressions explored issues of hybridity, self and identity and can best be subsumed under the conceptual metaphor or pun, based on the well-known name of a toy retailer:

- microbes aRe US

and

- humans are Hybrids 
Other metaphorical expressions exploited knowledge of how humans operate in the wider environment and were therefore based on the following conceptual metaphors:

- PaRTs of the human body/the human bOdy ARE/IS (AN) ECOSYSTEM(S)

- humans ARe SUPER-ORganisms.

A small number of metaphors focused on the activities around the HMP. Here the microbiome was, as the genome had been, conceptualised as unexplored territory that needs to be mapped. A last cluster of metaphors that we found was labelled 'other' and contained various nonce creations, or metaphorical one-off creations, such as "microbial gardening for weight loss" (Randy Seeley ${ }^{1}$ ), "an individual's internal bioreactor" and so on. Three expressions framed the microbiome as a person's unique fingerprint or signature (Blaser), tying advances in microbiomics to well-known promises made about the advent of personalised medicines.

These metaphors indicate novel scientific understandings of microbes and their relations with humans and this on four levels.

- Microbes are no longer conceptualised solely as enemies but also friends (buddies, helpers and so on), a conceptualisation that is also increasingly favoured by advertisers of probiotics products which want to appear 'scientific' (Koteyko \& Nerlich, 2007).

- Humans are no longer conceptualised as the pinnacle of evolution, standing apart from microbes seen as populating the bottom of the evolutionary tree: we are all human-microbe hybrids.

- Microbes are conceptualized not only as a danger to human health, but as (what some probiotics advertisers call) a 'boon' to human health. And what is more, microbes might be able to regulate more than just 'digestion', they

\footnotetext{
${ }^{1}$ Professor of Psychiatry and Associate Director of the Obesity Research Center at the University of Cincinnati College of Medicine.
} 
may be involved in regulating weight; in short, they may be recruited to save life rather than destroy it. The focus shifts from contamination to cooperation.

- And finally, a new understanding of 'life itself' seems to be taking shape: life has to be seen in a much less deterministic and much more fluid and flexible way:

As an article in New Scientist expressed it:

As a result, scientists are coming round to the idea that there is a continuum between our internal microbes and those inhabiting the outside world. With this change in thinking comes the realisation that it might be possible to manipulate the human microbiome to improve our health. Probiotic yogurt containing live bacteria is just the start; future prospects include caries-busting bacteria and perhaps even microbes to help you lose weight. (New Scientist, 15 August, 2007, italics added)

In this article we set ourselves the task to find some preliminary answers to the questions: What will be the likely impact of human microbiome research on existing concepts of 'self' and 'personal identity'? And: What will be the likely impact of human microbiome research on existing answers to the question: What is life? What does it mean to be human? What counts as a 'human body'? In the following we will therefore first explore the cluster of metaphors according to which MICROBES ARE US, before turning to the social life of microbes and their actions.

\section{Microbes, self and identity}

The articles that explored issues of self, identity and hybridity all used the pronouns we, you, us, I and so on in novel ways, in ways that blurred the boundaries between 
humans and microbes. Others highlighted the fusion of the two more directly by using words such as amalgam, mix, composite or hybrid. They would probably all subscribe to what one scientist said, namely that "To fully understand what it means to be human, we need to embrace, explore and explain what microbes mean to us" (Gordon). Whereas scientists raised issues of self and identity (Gordon, 2006), journalists made this story even more personal by addressing readers directly as you and exhorting them to change their view of what it means to be human and what it means to have a self:

So you think you are the self-reliant type. A rugged individualist. ${ }^{2}$ Well, give it up. You'd be nothing without the trillions of microbial minions toiling in your large intestine...

Are you feeling calm? Now listen carefully and don't panic. You are suffering from a serious crisis of identity. Scientists believe you are not entirely human. In fact, it's time to stop thinking of yourself as an individual, or even as a single living thing. You are a hybrid that consists of only about 10 per cent human cells.

You would be nothing without the trillions of microbial minions milling around your large intestine

Bacterial buddies make life - and you - possible

\footnotetext{
${ }^{2}$ As Dupré and O'Malley wrote in his recent article 'Varieties of life': "It is entirely reasonable to think of autonomy as centrally exhibited in cooperation rather than just rugged independence" (Dupré \& O’Malley, forthcoming 2009)
} 
You are not alone

Behold yourself, for a moment, organism. A trillion cells stuck together, arrayed into tissues and organs and harnessed by your DNA to the elemental goals of survival and propagation. But is that all? An electron microscope would reveal that you are teeming with other life-forms. [...] Where do you leave off, and they begin? Microbes, Relman holds, are "a part of who we are."

This provides insights into new ways of conceptualising the self and what it means to be human, especially through expression such as "You are a hybrid" or "a hybrid creature". The boundaries between self and other are blurred: "the self some of us try so relentlessly to improve is really community property"; "our microbial self" (Blaser); the self is "suffering from a serious crisis of identity". The self is here depicted more like a process than an object. It is a systems property, as Noble would say (Noble, 2006b).

The pronoun 'we' is used by scientists and journalists alike to stress the fluid boundaries between us and them:

[...] each of us, sick and healthy, could start speaking in the first person plural, not with the editorial, but the biological 'we'. We may not all have multiple personalities but it is fair to say that the self some of us try so relentlessly to improve is really community property.

We may or may not be what we eat, but we certainly are what lives within us 
It would thus broaden our philosophical horizons if we thought of a human as a more than an organism. We are superorganisms with an extended genome that includes not only our own cells but also the fluctuating microbial genome set of bacteria and viruses that share our bodies. (Lederberg)

We may not be entirely human...we may be truly symbiotic organisms relying on one another for life itself

We are somehow like an amalgam, a mix of bacteria and human cells

We're really a composite of many species, an amalgamation of human and microbial attributes. (Gordon)

Microbes [...] are "a part of who we are." xx

Each of us is a singular crowd - a walking, talking, air-breathing, wasteproducing assemblage of microbial organisms.

[...] the DNA-based approach has the potential to reveal at last the metabolic details of our many mini-mes (Fraser-Liggett)

As indicated in the introduction, Nobel had asked in 2006 whether insights from systems biology may change "our philosophy, in the full sense of the term". Here we see emerging a language that frames view of life and the self as plural and fluid, which indicates such a change. The HMP is therefore celebrated as "An ambitious 
project that promises to extend humanity's view of itself". We are plural selves, but also extended selves (which includes extended genomes). This view of the extended self as portrayed in the media overlaps substantially with scientific views as set out in an influential paper by Gordon et al entitled: "Extending Our View of Self: the Human Gut Microbiome Initiative (HGMI)" (Gordon et al., 2005; see also Turnbaugh et al., 2007). And, as Lauren Seiler has recently pointed out:

How we construct the human biological self has consequences for understanding our health, how we reproduce, and what we are. These social constructions greatly influence our views on abortion, stem-cell research, human cloning, and our post-human future. A more accurate construction of the human biological self will help us better navigate these contentious issues. (Seiler, 2007)

\section{Body and environment}

Our newspaper analysis points to new views of the self and also of the human body, conceptualised no longer as a singular and closed container (THE HUMAN BODY IS A CONTAINER) but, like the microbes that inhabit it, a type of society (THE HUMAN BODY IS A SOCIETY) which interacts constantly with other such societies and the environment in which they live, to such an extent that one cannot be "sure where the super-organism ends and the environment begins" (DeLong). In short: "The average human is more microbe than mammal, a veritable super-organism comprising 10 times as many microbial cells as human cells." This view of the body as society reverses a more classical metaphor, widely used in political discourse, of societies as organisms or of the state as a 'body politic' (Musolff, 2004).

This brings us back to another pervasive cluster of metaphors found in our corpus, that of MiCROBES AS SOCIAL GROUPS and MiCROBES AS AGENTS. Humans are not 
the only agents or the only beings that live in social groups. They actually depend on the actions of microbes and their 'social interactions' to alive and stay healthy.

The dominant metaphor is the one according to which microbes live in or are "communities". In microbiology the term community is not used in a metaphorical way, though. It becomes or gains metaphorical power however when used in connections with other words and in a media rather than science context. In the media microbial communities are sometimes called "luxuriant communities" $x x$ or, if talking about "families", they have distant relatives and cousins, -- both in terms of distant relatives but also cousins. "And not just first cousins, but second, third and fourth cousins" (Blaser). They can be seen as a "population", a "colony" or even as a "nation". They can also be "neighbours" (Michael Gilmore) 3 or or "co-inhabitants". If the body is seen as a house, they can become "tenants homesteading in our bodies" which pay us some sort of "rent". If the body is seen as a vehicle, they can become passengers, but not mere passengers, as they actually do things for us. If the body is seen as a city, they can be conceptualised as "tourists" (Blaser) and "there is a lot of transiency" (Blaser); there are "residents" (Blaser) and "visitors" and "migrants". But most importantly they are our "friends" and our "guts little helpers", even our "minions". They are our "wee buddies" and our "closest compadres". Sometimes they are seen as "majority shareholders" and as "a gastrointestinal consortium" (Gordon), "a parliament of the bowels" (Gordon), sometimes as "aliens", but "mostly friendly" ones (only one headline tells us that there is an "Inhuman DNA in Every Person", which sounds more ominous); they are an "alien nation", in fact they are "the closest of aliens". Sometimes they are framed as animals, as "good grazers" (Gordon) or as animals inhabiting a "veritable zoo" or a "virtual zoo" or a "real zoo", or a

\footnotetext{
${ }^{3}$ Departments of Ophthalmology and Microbiology, The University of Oklahoma Health Sciences Center.
} 
"menagerie", but a zoo we haven't really explored yet. As one scientist (Blaser) said, using an extended metaphor: "It's like we're at the zoo, but so far we've just looked in the primate house. We haven't even gotten to the cat house or the elephant house".

As indicated above, these social little creatures are agents, and this in many ways. They are mostly friendly helpers that "are on our side", fight off newcomers, help us digest, help keep us alive, break down toxins, educate the immune system, cultivate, manufacture, toil away, feed us, produce, regulate, adjust, graze, fuse, form barriers, and these are only some of the actions or functions that could be listed. Only once are they seen as 'ganging up on humans'.

This extended view of 'agency' chimes in with what Noble said on a blog:

There is no privileged level of causality in tissues, organs, systems, organisms and even the organism's environment -- all may be causal agents that determine whether or not an organism survives to reproduce itself and hence to determine the process of evolution. I am proposing therefore a theory of biological relativity. (Noble, 2006b)

\section{Communities and communication}

One aspect of agency is of particular importance to scientists and this is the ability of microbes to communicate, indeed 'chatter' with each other - an essential part of social life and social intelligence as we all know! Only a small section of the press coverage deals with this issue of communication between microbes, something that is however a big issue for microbiologists (Goldenfeld \& Woese, 2007).

The most intriguing question is how microbes interact with each other and with our own cells. "There is a three-way conversation going on throughout 
our bodies," says Jane Peterson of the National Human Genome Research Institute. "We want to listen in because we think it will fill in a lot of blanks about human health--and human disease." (Newsweek, 29 October 2007)

And we should listen, because, as Gordon pointed out, microbes may very well be "educating our immune system". Going beyond mere communication and conversation we can also develop "co-conspiracies with bacteria" (Gordon). Such communication metaphors clash with classic metaphors of 'reading the book of life', where reading is a completely unidirectional process and the genomes we read are entirely passive. Whereas in the HGP metaphors based on 'communication' focused on aspects of information transfer, here metaphors of communication focus on interaction and conversations between microbes and between microbes and humans.

\section{Conclusion}

In this article we asked whether the HMP provides a novel answer to the question: What does it mean to be human? Whereas the HGP tried to pin the answer to this question to a single place, namely the genome, in a rather deterministic way, the alternative answer to this question, provided by those studying microbes, is less deterministic and much more fuzzy. It is based on a new view of what it means to be human which extends over numerous genomes, from 'our' genome to the genomes of microbes and beyond to interactions between microbes, humans and the wider environment. This also means that notions of the self has become diluted and pluralised and 'man's' dominion over nature is questioned.

After the initial excitement about the HGP had subsided, scientists like Noble tried to establish a new way of seeing genetics and genomics that would no longer be based on genetic determinism and reductionism, that is, on what he called the reductionist causal chain leading from genes to proteins to pathways to sub-cellular 
mechanism to cells to tissues to organs and finally to organisms. A whole language had been built around this view and had pervaded genetics and genomics for a long time, especially efforts to decipher 'the book of life'. Noble tried to replace this pervasive metaphor with another one, 'the music of life' and to lead scientists away from single genes to whole systems and interactions between elements of the system.

The language used in covering advances in research dealing with the human microbiome seems to be pointing in the same direction in science as well as the media, where journalists seem to follow scientists' metaphorical lead but make the message about microbes as personified agents even more personal through direct appeals to the reader and the introduction of variety into the metaphorical communities used by scientists themselves.

If we are all superorganisms and if the boundaries between self and microbes and microbes and environment and, not to forget, microbial and human genomes are fluid, then ecological metaphors emphasising complex interactions between species, or between humans and microbes are better at capturing increasingly more complex genomic research than those highlighting libraries, books, reading and writing used in the previous biosciences debates, in particular in the HGP. It is therefore not astonishing to find that the language used to talk about the microbiome is redolent with interaction metaphors or 'integration' metaphors. This is quite similar to the language used in systems biology where living organisms are seen as assemblages of simpler organisms. Traditional genetics saw the body as a container for genes sealed off from the outside world, whereas integrationist systems biology and microbiomics see the body as merging with its environment with genes moving to and fro.

However, in some parts of the press coverage of the HMP, the old concept of the 'selfish gene' (Dawkins, 1976), which can be seen as part of a reductionist view 
of biology, seems to be replaced by a similarly reductionist view of the 'selfish microbe'. A UK scientist from Imperial College (Jeremy Nicholson) is for example quoted as saying: "Indeed, it is tempting to suggest that the role of the host is to function as an advanced fermenter, carefully designed to maximise the productivity of the microbiome." (The Independent, 17/07/2007) This was however not the dominant framing.

In the biosciences the concepts of life and of organism and with it the concept of the human body, the self and of what it means to be human are changing. This has implications for the language of biology, as Goldenfeld \& Woese (2007) have pointed out. It also had, as we have seen, implications for the language of the English speaking press reporting on advances in microbiomics. Will this new type of language related to microbes and the microbiome lead to changes in public understanding of bugs, germs and bacteria and what it means to be human? We will have to wait and see. Publicity surrounding bad germs causing hospital acquired infections and now community acquired MRSA might still prevent this from happening (Nerlich, in press). A re-emergence of deterministic language around synthetic biology might also be a barrier to such a change in perspective (Hellsten \& Nerlich, in prep.). However, new less deterministic and more integrationist conceptualizations are out there in science and society and are just waiting to be used more widely to find new answers to the question: What does it mean to be human? These answers have to focus not only on us humans alone but on the whole (microbial) planet. Both human health and our planet's health may well depend on it.

\section{Acknowledgements}

This article has emerged from a horizon scanning exercise at the end of a project funded by the Economic and Social Research council: 'Enlisting the help of friendly bacteria: Probiotics and visions of health, nutrition and science in a modern world'. 
Grant number: RES000222289. We also thank both Denis Noble and John Dupré for sharing their thoughts and manuscripts with us. We would also like to thank Professor Jacqueline Broerse and the anonymous reviewers for their helpful comments.

\section{References}

Anonymous (2008) Will systems biology bring probiotics to the table?

The Seven Stones Blog. Available at: Http://Blog msb.Embo.Org/Blog/2008/01/Will Probiotics Bring Systems.Html [Accessed 20 February, 2008]

Avise, J.C. (2001) Evolving genomic metaphors: A new look at the language of DNA. Science, 294, pp. 86-7.

Blaser, M. (2006) Who are we? Indigenous microbes and the ecology of human diseases. EMBO Reports, 7, pp. 956-60.

Crawford, P., Brown, B., Nerlich, B. \& Koteyko, N. (2008) The moral careers of microbes and the rise of the matrons: An analysis of UK national press coverage of methicillin resistant staphylococcus aureus (MRSA) 1995-2006. Health, Risk \& Society, 10(4), pp. 331-347.

Dawkins, R. (1976) The Selfish Gene (Oxford, Oxford University Press).

DeLong E. F. 2004. Microbial population genomics and ecology: a new frontier. In Microbial Genomics, ed. C.M. Fraser, K. E. Nelson, T.D. Read, Human Press Inc., Totowa, N.J., pp 419-442.

Doney, S. C., Abbott, M. R., Cullen, J. J., Karl, D. M., \& Rothstein, L. (2004). From genes to ecosystems: The ocean's new frontier. Frontiers in Ecology and the Environment, 2(9), pp. 457-466

Dupré, J. and O'Malley, M.A. (forthcoming, 2009). Varieties of living things: Life at the intersection of lineage of metabolism. Synthese. 
Gill, S.R. et al. (2007) Metagenomic analysis of the Human Distal Gut Microbiome. Science, 312, pp. 1355-59.

Goldenfeld, N. \& Woese, C. (2007) Biology's next revolution. Nature, 445, p. 369. Gordon et al. (2003) Response From Jeffrey I. Gordon et al.: Commensal bacteria make a difference. Trends in Microbiology, 11, 150-151.

Gordon et al. (2005) Extending our view of self: The Human Gut Microbiome Initiative (HGMI). Bethesda, MD, National Human Genome Research Institute. Available At: Http://Www.Genome.Gov/Pages/Research/Sequencing/Seqproposals/Hgmis eq.Pdf [Accessed 20 February, 2007].

Hellsten, I. \& Nerlich, B. (2008) Genetics and genomics: The ethics and politics of metaphorical framing In: Handbook of Public Communication of Science and Technology, Eds. M. Bucchi, B. Trench (London, UK: Routledge), 93-109.

Hellsten, I. \& Nerlich, B. (in prep.) The semantics of synthetic biology, article manuscript in preparation.

Knudsen, S. (2005) Communicating novel and conventional scientific metaphors: A study of the development of the metaphor of genetic code. Public Understanding of Science, 14(4), pp. 373-92.

Kotekyo, N. \& Nerlich, B. (2007) Multimodal discourse analysis of probiotic web advertising. The International Journal of Language, Society and Culture, 23. Available At:

Http://Www.Educ.Utas.Edu.Au/Users/Tle/JOURNAL/Issues/Issue23-07.Html

Lakoff, G. \& Johnson, M. (1980) Metaphors We Live By (Chicago, University of Chicago Press).

Lopez, J. J. (2007). Notes on metaphors, notes as metaphors: The genome as Musical spectacle. Science Communication, 29(1), pp. 7-34. 
Martin, F. et al. (2007) A top-down systems biology view of microbiomemammalian metabolic interactions in a mouse model. Molecular Systems Biology, 3

McManus, R. (2005) More Microbe Than Human: Relman's Investigations Prove We Are Never Alone. NIH Record Vol. LVII, No. 24: http://nihrecord.od.nih.gov/newsletters/2005/12_02_2005/story03.htm[Acc essed 2 October 2008]

Musolff, A. (2004) Metaphor and Political Discourse: Analogical Reasoning in Debates About Europe (London, Palgrave Macmillan).

NERC (2006). What is genomics and post-genomics? Natural Environment Research Council:

http://www.nerc.ac.uk/research/programmes/proteomics/background/whati s.asp [Accessed 2 October, 2008]

Nerlich, B. (2008, in press) The antibiotic apocalypse' and the 'war' on superbugs: The risks and benefits of catastrophe discourse (With a reply by Richard James). Public Understanding of Science.

Nerlich, B., Dingwall, R. \& Clarke, D. D. (2002). The Book of Life: How the human genome project was revealed to the public. Health: An interdisciplinary journal for the social study of health, illness and medicine, 6(4), pp. 445-69. Nerlich, B. \& Dingwall, R. (2003) Deciphering the human genome, In R. Dirven, R. Frank and M. Pütz (Eds) Cognitive Models in Language and Thought: Ideology, Metaphors and Meanings, Berlin, Mouton De Gruyter, pp. 395-428. Nerlich, B. \& Hellsten, I. (2004) Genomics: Shifts in metaphorical landscape between 2001 and 2003. New Genetics and Society, 23, pp. 255-68. Nerlich, B. \& Kidd, K. (eds.) (2005) Special Issue: The Genome and Its Publics: Towards a Social and Cultural Understanding of Genomics. New Genetics \& Society, 24. 
NIH (2007) Press Release: NIH Launches Human Microbiome Project. NIH.

Available At: Http://Www.Nih.Gov/News/Pr/Dec2007/Od-19.Htm [Accessed 20 February, 2007].

Noble, D. (2006a) The Music of Life (Oxford, Oxford University Press).

Noble, D. (2006b) Re: Systems Biology -- The Music of Life and the Theory of (Biological) Relativity. ACTA. Available At: Intentblog: Available at: Http://Www.Intentblog.Com/Archives/2006/10/Prof Denis Nobl.Html [Accessed 20 February, 2007].

Ouzounis, C., Mazière, P. (2006) Maps, books and other metaphors for systems biology. Biosystems, 85, pp. 6-10.

Pappas, G. (2005) A New Literary Metaphor for the Genome or Proteome. Biochemistry and Molecular Biology Education, 33, p. 15.

Picton, G. (2007) BCM Human Microbiome Projects to sequence 150 bacteria, sample Human Metagenome. Houston, Baylor College of Medicine.

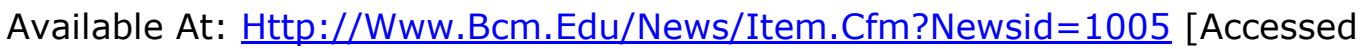
20 February, 2007].

Porta, M. (2003) The new genome sequence is a jazz score. International Journal of Epidemiology, 32, pp. 29-31.

Relman, D. A. (2002) The human body as microbial observatory. Nature Genetics, 30, pp. 131-33.

Relman, D. A. and Falkow, S. (2001) The meaning and impact of the human genome sequence for microbiology. Trends in Microbiology, 9(5), pp. 206-08.

Richards, I. A. (1936) The Philosophy of Rhetoric (Oxford, Blackwell).

Schmitt, R. (2005) Systematic metaphor analysis as a method of qualitative research. The Qualitative Report, 10, pp. 358-94. Available At: Http://Www.Nova.Edu/Ssss/QR/QR10-2/Schmitt.Pdf [Accessed 20 February, 2007]. 
Seiler, L. H. (2007) What are we? The social construction of the human biological self. Journal for the Theory of Social Behaviour, 37(3), pp. 243-77.

The National Academies (2007). Understanding our Microbial Planet: The New Science of Metagenomics:

http://dels.nas.edu/dels/rpt briefs/metagenomics final.pdf [Accessed 2 June 2008]

Tomes, N. (1998) The Gospel of Germs: Men, Women and the Microbe in American Life (Cambridge, MA, Harvard University Press).

Turnbaugh, P.J et al. (2007) The Human Microbiome Project. Nature, 449, pp. 80410. 